\title{
The Demonism of Creation in Goethe's Philosophy
}

Nicolae Râmbu ${ }^{I}$

\begin{abstract}
Goethe's philosophy of creativity revolves around what he called das Dämonische. This essay is not meant as a definition or an explanation of demonic creation, but instead presents a demonic work par excellence, as the term "demonic" is defined by Goethe in the Elegy from Marienbad. The process of the creation of this work, as it is described by Goethe, also represents a strange exorcism, as the entire daemonic creative force of the author is transposed in this lyrical masterpiece of German and universal literature. After writing the Elegy Goethe, it is no longer demonic.
\end{abstract}

KEYWORDS: Philosophy of creativity. Goethe. Demonic personality. Faust. Genius.

\section{About a STrange eXorCise: THE ELEG Y From Marienbad}

In one of his discussions with Eckermann regarding the demonic, Goethe makes the following mentioning which is often quoted in the works dwelling upon this subject, that "[...] in poetry, especially in that which is unconscious, before which reason and understanding fall short, and which therefore produces effects so far surpassing all conception, there is always something dæmonic." 2 The demonic, as Goethe repeatedly maintains, should not be confused with the diabolic. It represents the mysterious power which can be manifested not only in certain personalities but in things, events or entire epochs. In Poetry and Truth the author says "[...] this demoniacal element can manifest itself in all corporeal and incorporeal things, and even expresses itself

\footnotetext{
${ }^{1}$ Faculty of Philosophy, University "Al.I.Cuza” Iaşi, B-dul Carol I, 11 Iasi, 700506 Romania. E-mail address: nikolausrambu@yahoo.de

${ }^{2}$ ECKERMANN, Johann Peter. Conversations of Goethe by Johann Peter Eckermann. Translated by John Oxenford. London: George Bell \& Sons, 1906, Tues., Mar. 8., 1831.
} 
most distinctly in animals." ${ }^{3}$ Therefore, we can't but be surprised by the fact that Goethe asserts that the demonic may take the strangest forms in animals since a fragment of the New Testament chosen by Dostoyevsky was to serve as an epigraph for his famous novel The Daemons, which was based on this. Based on the Gospel According To Luke a demonized person was healed by Jesus because he "[...] had commanded the unclean spirit to come out of the man" (LUKE, 8.29). Demons pass from humans to animals, they rush to a cliff towards the sea and get drowned. "Then people came out to see what had happened, and when they came to Jesus, they found the man from whom the demons had gone sitting at the feet of Jesus, clothed and in his right mind. And they were afraid. Those who had seen it told them how the one who had been possessed by demons had been healed." (LUKE, 8.35-36).

In order to support the idea underlined in the present essay, the fact that the demon, or in Goethe's vision the demonic, manifests itself both in humans, animals and things, which is not so important as it is its shift from one to another. It goes without saying that both Goethe's demonic and the exorcise dwelled further upon having almost nothing to do with the ones related in the New Testament passages mentioned above nor with the mystical and occult practices originating there, nevertheless this analogy is necessary. Like the unclean spirit from the biblical story, Goethe's demonic comes out of him and passes this time not into an animal but into a thing, which can be found in the fascinating Elegy from Marienbad.

People moved by this mysterious force, known by Goethe das Dämonische, behave like actual instruments in the hand of a mighty force which fatally traces the road to be followed in order to reach a certain goal. Goethe himself says that "[...] something Dæmonic prevailed, which was not to be resisted" " which determined him to write the Metamorphosis of Plants and to meet Friedrich Schiller in a certain circumstance or to travel at a certain time to Marienbad. He is fascinated by demonic personalities, such as Napoleon or Byron, nevertheless Goethe specifies that demonic people "[...] always the most eminent men, either morally or intellectually; and it is seldom that they recommend themselves to our affections by the goodness of hearing!: a tremendous energy seems, to be seated in them; and they exercise a wonderful power over all creatures, and even over the elements; and, indeed,

\footnotetext{
${ }^{3}$ GOETHE, Johann Wolfgang. Poetry and Truth. Bucharest: E.P.L., 1967, vol. III, p. 386.

${ }^{4}$ ECKERMANN, Johann Peter. op. cit., Sun., Mar. 20, 1831.
} 
who shall say how much farther such influence may extend? All the moral powers combined are of no avail against them." ${ }^{5}$

We will try to illustrate the daemonic element in the artistic creation by one of Goethe's works. We will refer particularly to the Elegy from Marienbad in order to highlight the extraordinary relation between a daemonic author, Goethe and his work. Generally, "[...] when a work was finished, it became uninteresting to me; I thought of it no more, but busied myself with a new plan." ${ }^{\prime}$ Nevertheless, Goethe had a special relation with two of his works. The first one is The Sorrows of Young Werther, the other one is par excellence, which is a demonic work is Elegy from Marienbad. Although, both of them saved Goethe from some desperate situations these two works represent at the same time two extremes of the way in which their author saves himself by transposing his suffering into poetry.

\section{A воOK LIKE A “POSTPONED SUICIDE”}

The Romanian philosopher Emil Cioran said that "[...] any book is a postponed suicide". The Sorrows of Young Werther is a perfect illustration of Cioran's idea, as stated above. If we refer strictly to the epic plan, this book about suicide is the one which really saved Goethe from the suicide that could be not "postponed" otherwise. This is not an interpretation or a speculation but Goethe's testimony in Poetry and Truth:

By these convictions I freed myself, not so much from the danger as from the whim of suicide, which in those splendid times of peace, and with an indolent youth, had managed to creep in. Among a considerable collection of weapons, 1 possessed a handsome, well polished dagger. This I laid every night by my bed; and, before 1 extinguished the candle, I tried whether I could succeed in plunging the sharp point a couple of inches deep into my heart. Since 1 never could succeed in this, I at last laughed myself out of the notion, threw off all hypochondriacal fancies, and resolved to live.?

At this turning point in Goethe's life, the masterpiece The Sorrows of Young Werther is born. Subsequently, this is what Schleiermacher called, using

\footnotetext{
${ }^{5}$ GOETHE, Johann Wolfgang. Poetry and Truth.Bucharest: E.P.L., vol. III, 1967, p. 387.

${ }^{6}$ ECKERMANN, Johann Peter. op. cit., Wed., April 14. 1824.

${ }^{7}$ GOETHE, Poetry and Truth, op. cit., vol. cit. p. 167.
} 
a term difficult to render in another language, Keimentschlu $\beta,{ }^{8}$ which was the seed that germinated and gave birth in the author's soul in his next work. The Sorrows of Young Werther represents, as it results from Poetry and Truth, a real "postponed suicide", because according to Goethe only the "suicide fixation" was thus defeated without the suicide "project" for he will need this plan at a certain moment in his life as part of the survival strategy.

In order to detach himself temporarily from the "suicide fixation", Goethe determines Werther to commit suicide for him, creating thus a character who decides to die so that his creator may live. This is one of Goethe's shocking testimonies regarding the origin of The Sorrows of Young Werther: "[...] but, to be able to do this, with cheerfulness, I was obliged to solve a poetical problem by which all that I had felt, thought, and fancied upon this important point should be reduced to words."

If we make a distinction like Goethe does between the "suicide fixation" and the "suicide project", which is nothing else but a less fix idea that we should accept regarding the last play as being an essential part in keeping the human's dignity until the very last moment of his life. For when dignity it is brutally cancelled, the "suicide project" must be put in application so that the life could maintain its sparkle until the very end. This is the main idea of the Stoicism and of other several philosophies, which gave suicide the place it deserved in the human's axiological universe and reflected profoundly upon it. By means of his character, he does not reflect only on the suicide but he also upon suicides imaginarily or better said aesthetically. The Sorrows of Young Werther expresses the strange tragic joy produced by the thought that somebody sacrifices in you in their place and that a dear person dies so that you can continue living. That is why the author's relations with this work have always been tense. Goethe will come back to The Sorrows of Young Werther like a criminal to

\footnotetext{
${ }^{8}$ SCHLEIERMACHER, Friedrich Daniel Ernst. Hermeneutik und Kritik. Frankfurt am Main: Suhrkamp Verlag, 1995, p. 189.
}

${ }^{9}$ GOETHE, op. cit., vol. cit., p. 167. 
the crime scene. He often talked about his weird disposition when he was forced to reopen the pages he had written in order to get rid of the "suicide fixation". Unlike his usual behaviour, Goethe tells nobody about this creation during its becoming. It is like a secret and that is why Goethe's friends are surprised when they are offered the manuscript of The Sorrows of Young Werther in order to read it at the end of creation process, i.e. the four weeks.

For by this composition, more than by any other, I had freed myself from that stormy element, upon which, through my own fault and that of others, through a mode of life both accidental and chosen, through design and thoughtless precipitation, through obstinacy and pliability. I had been driven about in the most violent manner. I felt, as if after a general confession, once more happy and free, and justified in beginning a new life. ${ }^{10}$

A tragic reality had thus become a masterpiece of German literature.

After he had saved Goethe from suicide, the book about the sorrowfull Werther has still a rather perverse effect: it drives people crazy and makes them sick, the "Wertmania" becoming a malady, which pervades the spirit of the time. By a mysterious process the "suicide fixation" of which Goethe freed himself by writing The Sorrows of Young Werther, is transferred to the public. Here it is the author's confession in this respect:

But while I felt relieved and enlightened by having turned reality into poetry, my friends were led astray by my work ; for they thought that poetry ought to be turned into reality, that such a moral was to be imitated, and that, at any rate, one ought to shoot oneself. What had first happened here among a few, afterwards took place among the larger public; and this little book, which had been so beneficial to me, was decried as extremely injurious. ${ }^{11}$

As Madame de Staël said, Werther caused more suicides than the most beautiful woman in the world. How were the persons with suicidal tendencies supposed to react to The Sorrows of Young Werther? It was not Goethe's character, the one who should have been imitated but the author of this character. In Poetry and Truth, Goethe dedicates many pages to The Sorrows of

\footnotetext{
${ }^{10}$ Ibidem.

${ }^{11}$ Ibidem, p. 170-171.
} 
Young Werther, as if still amazed by the devastating effect of the book on the audience. In addition, the amazing success of a book tells always more about the audience itself than about its intrinsic value or about its author. Goethe himself was aware of the fact that the success of the book was due to the fact that it appeared at the right time, that age being hunted by the idea of suicide. Therefore not only has The Sorrows of Young Werther caused a massive wave of suicides, instead many self-murderers wanted probably to be associated with Werther and their gesture acquiring thus a highly spiritual connotation "The effect of this little book was great, nay. immense, and chiefly because it exactly hit the temper of the times. For as it requires but a little match to blow up an immense mine, so the explosion which followed my publication was mighty, from the circumstance that the youthful world had already undermined itself: and the shock was great, because all extravagant demands, unsatisfied passions, and imaginary wrongs were suddenly brought to an eruption." 12 The suicide of Jerusalem, which had a great echo in that time, also contributed to this, people believing that they found more about this by reading The Sorrows of Young Werther. Moreover, Werther had almost nothing in common with Jerusalem for it was Goethe himself the one who actually led the suicide to the very end in the poetic plan so that he could continue living.

Furthermore, what is there to be done when you are not capable of postponing your suicide by a masterpiece the way genius do? If you are not capable of creating a Werther, who could commit suicide in your place, then the way of the fabulous character did with its creator, Goethe's Werther remains the only chance to survive. The really strong characters seem to have understood this since as "[...] Napoleon read this work 7 times and in his campaign in Egypt, he did not leave it aside." ${ }^{13}$ Maybe all the people who wish to go beyond the veil could postpone their decision or even drop it for good, by reading The Sorrows of Young Werther. In fact this is the abstruse meaning of the author's preface to this thrilling book: "And thou, good soul, who sufferest the same distress as he endured once, draw comfort from his sorrows; and let this little book be thy friend, if, owing to fortune or through thine own fault, thou canst not find a dearer companion." ${ }^{14}$

Therefore, I shall quote again from Emil Cioran's, using his subtle formulation not only from the author's perspective but also from the one of

${ }^{12}$ GOETHE, op. cit., vol. cit., p. 173.

${ }^{13}$ GUNDOLF, Friedrich. Goethe, vol. I. Bucharest: Minerva, 1971, p. 299.

${ }^{14}$ GOETHE, The Sorrows of Young Werther, Bucharest: E. S. P. L. A., 1960, p. 1. 
the reader, a great book is a postponed suicide or, at least, it should be. The ones who committed suicide with Werther in their pocket would have done anyway. For them the jeopardy came from another direction, not from this book which should it be understood deep down could have been for most of the suicides the only possible salvation. Goethe saved himself by creating a masterpiece; the suicides affected by "Werthmania", which could have save themselves by admiring it.

\section{THE DEMONISM OF CREATION ${ }^{15}$}

The second work with which Goethe had a special relation is the Elegy from Marienbad, but the author's reaction is totally opposite to the one he had in The Sorrows of Young Werther. It is notorious that Goethe avoided any reencounter with this work for a reason clearly stated in his discussions with Eckermann: "Besides, as I have often said, I have only read the book once since its appearance, and have taken good care not to read it again. It is a mass of congreve-rockets. I am uncomfortable when I look at it; and I dread lest I should once more experience the peculiar mental state from which it was produced." 16

In what concerns the Elegy from Marienbad Goethe's reaction is at the opposite pole. He returns to it often and moreover he is completely fascinated by his own creation as of something demonic. Indeed, the Elegy from Marienbad is a demonic creation for a very special reason which we shall dwell further. Goethe's last love story which gave birth to this unique work in universal literature is well known. The poet aged 74, falls in love with Ulrike von Lewetzov whom he had met a year before when she was 18 years old in the same balneology resort in Bohemia. Goethe meets Ulrike in the summer of 1821 , at Marienbad, in her grandparents' house where she was lodged, he sees her again in 1822 in similar circumstances and in 1823, through the agency of prince Karl August, where Goethe officially asks her to marry him, his request being accompanied by a medical certificate which attested his physical capacity of fulfilling possible matrimonial obligations. ${ }^{17}$ The comic side of this situation was never overlooked by the ones who handled this episode

\footnotetext{
${ }^{15}$ A first version of the text that is to be published in Italian as Goethe e il potere demonico di Ulrike. In: Muse ribelli. Complicità e conflitto nel sentire al femminile, Verona: Ombre Corte Edizioni, 2011, p. 52-62.

${ }^{16}$ ECKERMANN, Johann Peter. op. cit., Fri., Jan. 2., 1824.

${ }^{17}$ See GERSDORFF, Dagmar von. Goethes späte Liebe. Die Geschichte der Ulrike von Lewetzow. Frankfurt am Main: Insel Verlag, 2005.
} 
in Goethe's life. Considered in a larger context, this scene is worthy of Don Quijote, because Ulrike von Lewetzov never acknowledged in her long life (1804-1899) that there existed any love story between them. Even towards the end of her life she used to say about her relationship with Goethe: "keine Liebschaft war es nicht." 18 This sentence- there was no love - expresses the essence of Ulrike's constant attitude towards Goethe's last love. When asked by her friend Malwine von Höfler, about what had happened between them at Marienbad, she answered: "I can assure you that Goethe gave me but a goodbye kiss." 19

Nevertheless for Goethe, this is a love story which lived in a totally different manner not only because it is the last one but because it becomes a creation which will free him from the demon for good. Both the creation of this poetry and its effects on its author are of miraculous nature. Here it is Eckermann's description of the almost magic atmosphere in which Goethe reveals for the first time his demonic work par excellence: "Stadelman brought in two wax lights, which he set on the table. Goethe desired me to sit down, and he would give me something to read. And what should this be but his newest, dearest poem, his Elegy from Marienbad?'20 Eckermann remarks the fact that Goethe's love affair in Marienbad was well known and that "[...] in this excited state, written a most beautiful poem, which, however, he looked upon as a sort of consecrated thing, and kept hid from every eye." ${ }^{21}$ Several elements related not only by Eckermann, but by other people in Goethe's entourage prove that "it was obvious that he prized this manuscript above all the rest." 22 At the same time, this elegy gave Eckermann a totally unusual impression, causing him trouble deep inside. This happened on October 27 $7^{\text {th }}$, 1823. According to Eckermann's notes on November $16^{\text {th }}$ the manuscript of the Elegy from Marienbad is presented again in the same magic atmosphere, in the trembling candle light. The poetry is read and reread "with rare a delight." 23 It is difficult for Goethe to detach himself from this poetry he loves as if it were the woman who inspired it. The Elegy remains unpublished for a long time and it is kept carefully together with other couple of objects which remind him

\footnotetext{
${ }^{18}$ Ibidem, p. 108.

${ }^{19}$ Ibidem, p. 109.

${ }^{20}$ ECKERMANN, Johann Peter. op. cit., Mon., Oct. 27., 1823.

${ }^{21}$ Ibidem.

${ }^{22}$ Ibidem.

${ }^{23}$ Ibidem, Sun., Nov. 16., 1823.
} 
of Marienbad. Wilhelm von Humboldt relates how during the visit he made to Goethe at Weimar, in November, 1823, he showed him this work telling him that it was the only one kept in his handwriting, and thus underlining the special meaning that he conferred to the Elegy from Marienbad.

In a splendid essay dedicated to Goethe, Stefan Zweig metaphorically places the appearance of the Elegy from Marienbad, amongst those astral hours of the human kind, when the human spirit is really creative. This piece of jewellery of German lyric is explained by Zweig by Goethe's theory on the "repeated puberty" of the genius. Goethe alleged that the erotic exuberance manifested in most people only when young is recurrent in geniuses. Moreover, the connection between the eros and the creation makes the object of numerous studies dedicated to the author of the Elegy from Marienbad. When very sick, his friend Karl Friedrich Zelter heals him by reading him his own poetry: "His grief was gradually assuaged, his last tragical hope was laid to rest, his dream of a life together with his beloved 'little daughter' had come to an end. He knew that never again would he go to Marienbad." ${ }^{24}$ Ulrike gave his puberty the occasion to manifest itself for the last time and this determines, according to Stefan Zweig, the deep pain expressed directly and "with great sincerity" ${ }^{25}$ in his poetry.

Nevertheless, we consider that a psychological explanation like Zweig's, the one who has a real Menschenkenner gift and who is at the same time a stylistic conqueror is not enough in order to understand Goethe's special relation with this poetry he had always considered a sacrosanct object. For the idea of liberation from demonism through the Elegy from Marienbad, which makes the object of this thesis highly illustrative are two quotations from Goethe: "[...] you see the product of a highly impassioned mood." In addition, he said "[...] while I was in it I would not for the world have been without it, and now I would not for any consideration fall into it again." ${ }^{26}$ Generally, it is the same feeling of liberation from a mysterious force "so rich in wealth, with danger far more fraught" (Elegy) also expressed in Faust, in the last moments of his life: "It's hard I know to free oneself from Demons, / the strong spiritbonds are not lightly broken." When Eckermann tells him that while reading it he had the feeling that the Elegy from Marienbad is nothing like other poetry of Goethe's, he says: "[...] that," said he, "[...] may be, because I staked upon

\footnotetext{
${ }^{24}$ ZWEIG, Stefan. Elegy from Marienbad. Bucharest: Musical Publishing House, 1978, p. 116.

${ }^{25}$ Ibidem, p. 115.

${ }^{26}$ ECKERMANN, Johann Peter. op. cit., Sun., Nov. 16., 1823.
} 
the present moment as a man stakes a considerable sum upon a card, and sought to enhance its value as much as I could without exaggeration." ${ }^{27}$

The Elegy from Marienbad requires a philosophical or, more precisely a metaphysical approach. There is no question regarding whether Goethe was a demonic man. This thesis is thoroughly substantiated by Gundolf so that there is no point to insist upon it. What we wish to underline here is the fact that of all the demonic people evoked by Goethe or who could easily be identified in history as being like that of Goethe himself is the only one who manages in the end to defeat his barbarian and destructive demonism in a titanic manner. It is true that Goethe underlines the fact that the demonic is a creative, positive and not negative force like Mephistopheles. Nevertheless, creation inevitably brings along destruction and quite often self-destruction. "The higher a man is," said Goethe, "[...] the more he is under the influence of demons, and he must take heed lest his guiding will counsel him to a wrong path." 28 The outrageous tension displayed by every reader of the Elegy from Marienbad feel that they would have destroyed Goethe himself or at least would have deviated him on wrong ways if he would not have managed to liberate himself through creation. Many other predecessors and successors of Goethe have done it. However, what makes this poetry unique in the cultural history is the fact that the entire demonic force of the author is transferred on the work like in a strange process of exorcism. The moment Goethe starts to write it down on paper The Elegy from Marienbad becomes a demonic work par excellence, and Goethe, its author, who is now liberated from the demon will continue to live and create like a simple genius if I may say so. After the Elegy inspired by Ulrike, he gravely takes an overview to his work built up during his 60-year life and it appears fragmented and scattered. Since he can no longer build he decides to gather it; he concludes the contract for his Collected Works, he can now count on royalties, he returns to his first companions of his youth Wilhelm Meister and Faust." ${ }^{29}$ This remark is found in most of Goethe's biographies. For instance Friedrich Gundolf says: "[...] almost everything Goethe will write from now on will consist of moral reflections and applications which are either calm, almost rigid or severe, energetic approvals and disapprovals uttered with

\footnotetext{
${ }^{27}$ Ibidem.

${ }^{28}$ ECKERMANN, Johann Peter. op. cit., Tues., Mar. 24., 1829.

${ }^{29}$ ZWEIG, Stefan. op. cit., p. 116.
} 
superiority." ${ }^{30}$ In other words, all the works Goethe written after the Elegy from Marienbad lacks demonism.

However, he will continue to be attracted by the Elegy as by a demonic work all his life. A series of confessions belonging to some of Goethe's close acquaintances may be invoked in order to support this idea. Marienbad started to have a miraculous effect on him from the moment he felt in love Ulrike von Levetzow in that place from Bohemia. At the beginning of 1823, Goethe was so ill that the doctors thought he would not live much longer. Goethe himself confessed to Doctor Huskhke: "I am lost" and the news of his death had already spread in Jena. ${ }^{31}$ When in agony Goethe uttered a redemption word: Marienbad! He wished to drink water from Marienbad and said that: "If I have to die, I want to do it my way!"32 both these waters that he drinks with all his being and the arnica tea (Arnikatee), flowers that Goethe says he found in Bohemia worked wonders. ${ }^{33}$ Naturally, after this "diet" followed by an improvement in his health condition not only imaginary but also confirmed by reliable person, Goethe suddenly rejuvenated wishes ardently to return to Marienbad.

On June $26^{\text {th }} 1823$, earlier thus than the previous years, the poet leaves for Bohemia where not only does he feel completely recovered after the severe illness he had suffered but he also lives the love story, which gave birth to the Elegy from Marienbad.

In order to understand better what we called Goethe's exorcise, by analysing this work, we should take a short look into the way the genius was perceived during those times. Although both are creative faculties, they have little in common. With his well-known synthesis capacity, Immanuel Kant defined the genius as "[...] the innate mental predisposition (ingenium) through which nature gives the rule to art" ${ }^{34}$, drawing attention at the same time on the danger which results from the spontaneity and originality of the genius. The counter-weight of the genius as creative faculty is according to Kant, the taste, the one which tempers the impetus of the genius of creating works which can be placed in a certain cultural tradition despite their

\footnotetext{
${ }^{30}$ GUNDOLF, Friedrich. op. cit., vol. III, p. 331.

${ }^{31}$ GERSDORFF, Dagmar von. op. cit., p. 47.

${ }^{32}$ Ibidem, p. 47.

${ }^{33}$ Ibidem.

${ }^{34}$ KANT, Immanuel. Kritik der Urteilskraft. Hamburg: Felix Meiner Verlag, 1993, p. 160.
} 
originality. "Taste... consists in disciplining (or training) genius. It severely clips its wings, and makes it civilized, or plished; but at the same time it gives it guidance as to how far and over what it may spread while still remaining purposive." 35

If the genius finds its counter-weight in taste as Immanuel Kant pointed out in the Critique of Judgment, the demonic as it appears in Goethe must also have a counter-weight in order not to deviate in wrong ways, as he says in one of his conversations with Eckermann. This time the counter-weight of the demonic is not taste but wisdom (die Weisheit). It shall not only calm the impulses of the demonic of which Goethe is possessed, but will substitute it for good after the exorcise represented by the Elegy from Marienbad:

Now am I far! And what would best befit The present minute? I could scarcely tell; Full many a rich possession offers it, These but offend, and I would fain repel. Yearnings unquenchable still drive me on, All counsel, save unbounded tears, is gone.

Flow on, flow on in never-ceasing course, Yet may ye never quench my inward fire! Within my bosom heaves a mighty force, Where death and life contend in combat dire. Medicines may serve the body's pangs to still; Nought but the spirit fails in strength of will. ${ }^{36}$

With this demonic creation, Goethe becomes wise, saying: "[...] why should I care such wisdom vast to know?" his inner balance is re-established after being completely confused by an equally demonic love as the elegy occasioned by it. Goethe's hypertrophied will specific to the demonic man ceases to exist after the Elegy from Marienbad. "To me is all, I to myself am lost,/Who the immortals' favourite erst was thought!" means nothing but that the demonic was left behind for ever.

${ }^{35}$ Ibidem, p. 175.

${ }^{36}$ GOETHE, Johann Wolfgang. Elegy from Marienbad.Translate by Edgar Alfred Bowring. 


\section{ConCLusion}

The Elegy from Marienbad is the work which best illustrates in terms of creation what Goethe calls das Dämonische. What I wanted to underline throughout this essay is the fact that this extraordinary creation unique in the history of literature also represents a strange exorcise process. The creation demon passes from Goethe's soul to the Elegy from Marienbad, which becomes itself a veritable demonic creation.

After this masterpiece Goethe's philosophy of creation suffers a radical transformation. The difference between Faust I and Faust II, around which so many disputes have existed, may be reconsidered based on the theory put forth in this essay. Friedrich Gundolf remarks that in the same way as Urfaust and Faust I occurred, Goethe's journey to Italy and between the two parts of Faust there is the transformation occurred in Goethe's spirit by Elegy from Marienbad.

The strange exorcise which occurred in the process of creation of this masterpiece, I think it may be understood best by analogy with one of the versions of the movie The Man who Walked Through Walls, based on the short story Le Passe-Muraille, de Marcelle Aymé. A man has the miraculous capacity of passing through the wall until this power is transferred to his lover in their effort of getting rid of the harassment of some journalists. Something similar happens with Goethe's demonism as it is entirely and for good transferred to the work inspired by a demonic love.

RÂMBU, Nicolae. O demonismo da criação na filosofia de Goethe. Trans/Form/Ação, Marília, v. 35, n.3, p. 67-80, Set./Dez., 2012.

RESUMO: A filosofia da criatividade de Goethe gira em torno do que ele denominou "Dämonische". Este ensaio não consiste numa definição ou numa explicação da criação demoníaca, pois apresenta um texto por excelência demoníaco, como o termo "demoníaco" é definido por Goethe no Elegy de Marienbad. O processo de criação deste texto, como é descrito por Goethe, também representa um exorcismo estranho, como toda a força criativa demoníaca do autor é transposta nessa obra-prima lírica da literatura alemã e universal. Após o Elegy de Goethe, a filosofia da criatividade já não é demoníaca.

PALAVRAS-CHAVE: Filosofia da criatividade. Goethe. Personalidade demoníaca. Fausto. Gênio. 


\section{REFERENCES}

ECKERMANN, Johann Peter. Conversations of Goethe by Johann Peter Eckermann. Translated by John Oxenford. London: George Bell \& Sons, 1906.

GERSDORFF, Dagmar von. Goethes späte Liebe. Die Geschichte der Ulrike von Lewetzow. Frankfurt am Main: Insel Verlag, 2005.

GOETHE, Johann Wolfgang. Poetry and Truth. Bucharest: E.P.L., 1967.

GOETHE, Johann Wolfgang. The Sorrows of Young Werther. Bucharest: E. S. P. L. A, 1960. GUNDOLF, Friedrich. Goethe. Bucharest: Minerva Publishing House, 1971.

KANT, Immanuel. Immanuel. Kritik der Urteilskraft. Hamburg: Felix Meiner Verlag, 1993.

RÂMBU, Nicolae. Goethe e il potere demonico di Ulrike. In: MARRONI, Aldo; TORO, Ugo di (eds),.Muse ribelli. Complicità e conflitto nel sentire al femminile. Verona: Ombre Corte Edizioni, 2011, p. 52-62.

SCHLEIERMACHER, Friedrich Daniel Ernst. Hermeneutik und Kritik. Frankfurt am Main: Suhrkamp Verlag, 1995.

ZWEIG, Stefan. The astral moments of humanity. Bucharest: Musical Publishing House, 1978.

Recebido em: 24.04.2012

Aceito em: 03.06.2012 